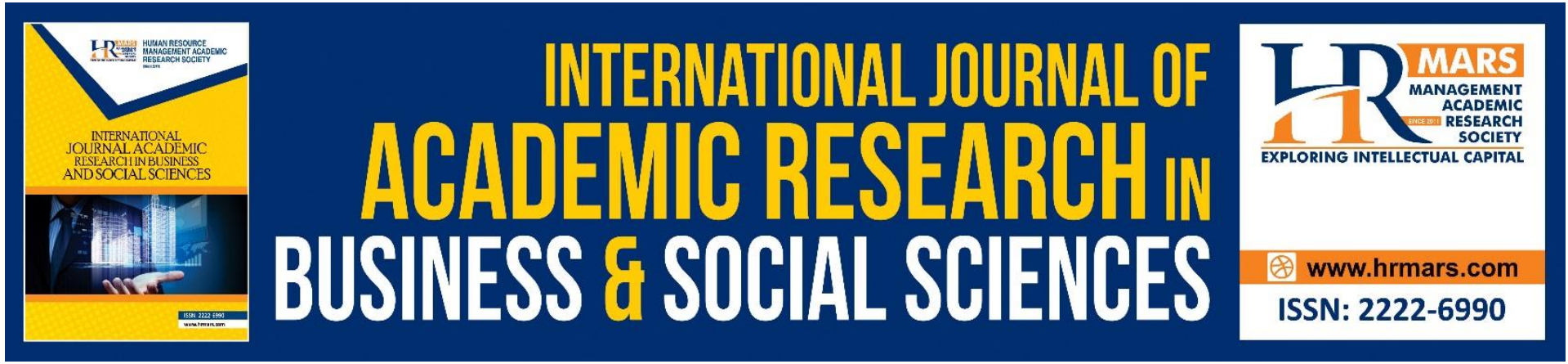

\title{
Predicting Factors towards Students Satisfaction among Private Universities in Selangor, Malaysia
}

\author{
Wong Chee Hoo, Alex Lee, Wong Yee Fong
}

To Link this Article: http://dx.doi.org/10.6007/IJARBSS/v11-i8/10676

DOI:10.6007/IJARBSS/v11-i8/10676

Received: 04 June 2021, Revised: 30 June 2021, Accepted: 21 July 2021

Published Online: 22 August 2021

In-Text Citation: (Hoo et al., 2021)

To Cite this Article: Hoo, W. C., Lee, A., \& Fong, W. Y. (2021). Predicting Factors towards Students Satisfaction among Private Universities in Selangor, Malaysia. International Journal of Academic Research in Business and Social Sciences, 11(8), 1890-1900.

Copyright: (c) 2021 The Author(s)

Published by Human Resource Management Academic Research Society (www.hrmars.com)

This article is published under the Creative Commons Attribution (CC BY 4.0) license. Anyone may reproduce, distribute, translate and create derivative works of this article (for both commercial and non-commercial purposes), subject to full attribution to the original publication and authors. The full terms of this license may be seen

at: http://creativecommons.org/licences/by/4.0/legalcode

Vol. 11, No. 8, 2021, Pg. 1890 - 1900

http://hrmars.com/index.php/pages/detail/IJARBSS

JOURNAL HOMEPAGE

Full Terms \& Conditions of access and use can be found at http://hrmars.com/index.php/pages/detail/publication-ethics 


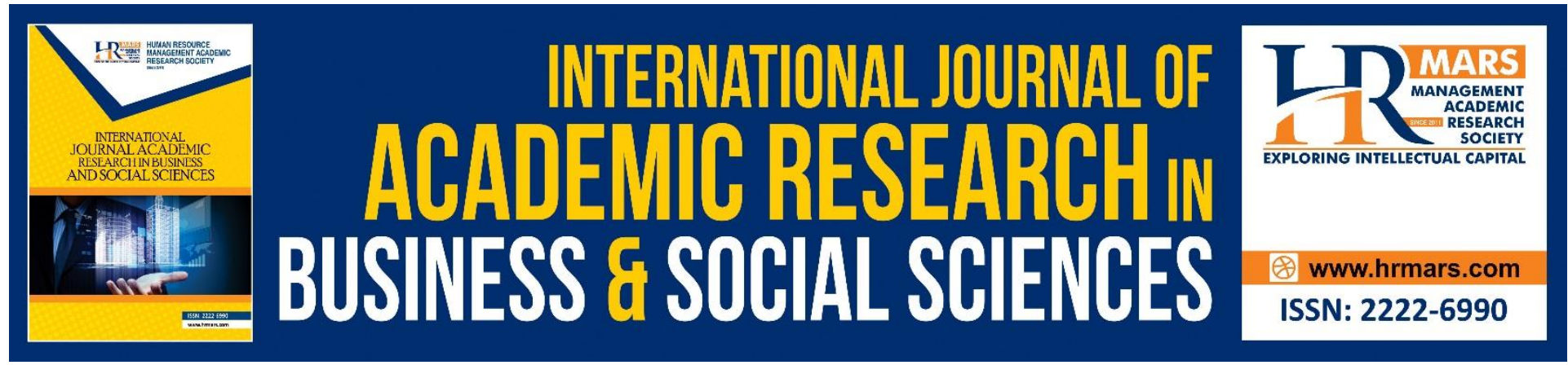

\title{
Predicting Factors towards Students Satisfaction among Private Universities in Selangor, Malaysia
}

\author{
Wong Chee Hoo
}

INTI International University, Malaysia

\author{
Alex Lee \\ University of Hertfordshire, United Kingdom. \\ Wong Yee Fong \\ INTI International University, Malaysia. \\ Email: cheehoo.wong@newinti.edu.my
}

\begin{abstract}
Student satisfaction, a factor that has been increasing in importance as it continues to influence the development and operation amongst private universities in Malaysia. This research focuses on this factor, amongst others, in their roles in affecting undergraduate students' satisfaction in private universities in Selangor, Malaysia. With higher education being an intangible service rather than a tangible product, this research seeks to hypothesis and analyse the relationship between service quality in the context of tangibility, assurance, reliability, responsiveness, and empathy. In this study, the research objectives and questions are highlighted, and a conceptual framework that integrates different factors influencing the satisfaction of undergraduates is proposed. A 5-point Likert scale survey $(\mathrm{N}=288)$ was conducted; data were analysed using Multiple Regression Analysis through SPSS. Three factors, tangibility, assurance and empathy showed a significant influence in predicting students' satisfaction amongst private university students.
\end{abstract}

Keywords: Tangibility, Assurance, Reliability, Responsiveness, Empathy, Students' Satisfaction, Private University.

\section{Introduction}

One of the many objectives in setting up a company is to achieve a high level of customer satisfaction (Drucker, 1954). This is proclamation, practised by many for many years, was further supported by Kotler (1977), quote, "looking at the whole business from the perspective of the final result, that is, from the perspective of customers" should be the main purpose of most, if not all, marketing activities. Hence the increasing importance of this factor.

Malaysia is the education destination for many international students. In 2018, 38 private universities hosted 130,110 international students from 163 countries, contributing greatly 
to the Malaysian economy. According to the Education Ministry of Malaysia, the revenue from international students expected to grow to RM15.6b (MalayMail.com, 2019). These achievements credited to the drive and innovation of Malaysian academia, the support of the private sector, and the deep investment from the government (Ministry of Higher Education (MoHE), 2015).

A research survey conducted in 2018 by Guilbault revealed that private university students view themselves as customers; a view that carries the connotation of high importance similar to that of a business client. This view is further strengthened in their awareness of consumer rights-a right that is expected in a service-led industry where a change of service provideruniversities can easily take place (Haihambo, 2018). SETARA, an executive ranking system which measures and compares the performance of private higher education institutions (PHE) in Malaysia also supports the enhancement of students satisfaction.

As with most, if not all, business, private higher education institutions in Malaysia depend on students' fees as one of the main income providers. Understanding the factors supporting student satisfaction, such as quality assurance, improving facilities, amongst others, are imperative steps to being sustainable for private universities. To understand these imperative steps and factors, the SERVQUAL model is deemed suitable for this research to underpin the theoretical understanding of the relationship between student satisfaction and the possible influencing factors: tangibles, assurance, reliability, responsiveness, and empathy. This study would also be able to determine which factor is the most crucial in satisfying the students in the universities.

\section{Literature Review \\ Undergraduates' Satisfaction}

Student satisfaction is defined as a key factor to measure the quality of education methods and the achievement of learning programs. Undergraduate's satisfaction is an important part of successful promotion of higher education (Duong, 2015). Disgruntled students may reduce the number of courses registered or simply drop out form studying the course (Kunanusorn and Puttawong, 2015).

Through a national survey of British college students, it was found that there were differences in student satisfaction in different research fields (Lenton, 2015). Previous studies have shown that the most important factors influencing student satisfaction are those related to teaching, while the least important factors are those related to physical facilities (Douglas, Douglas \& Barnes, 2006). Besides, recent studies have found that factors related to the academic atmosphere, such as teachers' response to students' needs, have a great impact on students' satisfaction (Li and Carroll, 2017). Controversially, only a few of these previous studies that attempted to measure the quality of higher education services using appropriate measuring model since there is no universal definition of quality at those previous times (Viraiyan and Ashley, 2016).

\section{Tangibles}

In a service business, all existing facilities that provide facilities, integrity, interior design and facilities should be considered, especially those closely related to what consumers directly perceive or obtain (Dora, 2017). Tangible substances are elements that can be "seen" and "moved" by students in university services (Afshan, 2018).

A study in Ho Chi Minh City, Vietnam, involving 4-star and 5-star hotels, has shown that tangibility could affect customer satisfaction as the result shows that there is a significant 
positive relationship between tangibles and customer's satisfaction (Phi, Thanh, and Nguyen, 2018).

The data from UK researches showed that, with a supported result of all hypothesises, it proved that tangibles have a positive significant relationship with customers' satisfaction in UK restaurants (Nguyen, 2018). Finding in the research data from Pakistan and Irbid city, Jordan confirmed that the hypothesis is accepted, which claimed that tangibles have a positive impact to customer's satisfaction (Ali and Raza, 2017; Al-Azzam, 2015). While research data from Jordan came out a result proved that tangibles have a significant positive relationship with passengers' satisfaction (Jahmani, 2017).

\section{Assurance}

A study defined that assurance is the knowledge of employees, and the capability to help the business to stimulate confidence and trust (Anwowie, Amoako and Abrefa, 2015). This dimension is important in determining the quality and risks and uncertainties that customers consider to involve high-level services. A study from USM Malaysia showed that with a supported hypothesis; there is a significant positive effect of good teaching on students' overall satisfaction (Thien and Jamil, 2019).

There is also data from researcher in Sri Lanka, Thailand, and University Utara Malaysia, with an accepted hypothesis, the result showed that there is a significant relationship connecting assurance and student's satisfaction (Kajenthiran, 2015; Kunanusorn and Puttawong, 2015; Pohyae, 2016),

Besides, data from Jordanian Governmental University showed that among the five dimensions of service quality, only Assurance and Empathy have a significant relationship to affect students" intention of moving (Twaissi and Al-Kilani, 2015), means that assurance could affect the students' satisfaction and making them moving to study at another university.

\section{Reliability}

The previous research study showed that reliability is the ability to increase reliably and accurately perform the services promised and the researcher of the study claimed that reliability is the most important determinant of consumers' perception of service quality and suggested that customers want to do business with organizations that keep their promises (Anwowie, Amoaka and Abrefa, 2015). Accordingly, all service providers, including private universities, need to understand customer expectations for reliability. In higher education, quality measures are growing, and there is an increasing emphasis on the reliability and responsibility of education (Abdullah, 2006).

From the data from researcher in Sri Lanka, and also the data from Institute Technology Indonesia, with an accepted hypothesis, both results showed that there is a significant relationship connecting reliability and students' satisfaction (Kajenthiran and Karunanithy, 2015; Theresia and Bangun, 2017).

Data from University Technology Malaysia showed the correlation between reliability and students' loyalty was 0.331 which signified a moderate and positive relationship between reliability and student loyalty (Sin, Yusof and Sin, 2018). As student loyalty must be achieved only after the service quality gained student satisfaction at the first place, therefore the data indirectly confirmed that there is a significant relationship among reliability and students' satisfaction.

There is also data from research from China University showed that there is a positive relationship between both lecturer assurance to students' educational achievement and 
lecturer dedication to the social incorporation of students and student satisfaction (Xiao and Wilkins, 2015).

\section{Responsiveness}

Responsiveness is the readiness to help customers and offer well-timed services. It is also communicated to customers by waiting for help or paying concentration to their inconvenience, criticism and requests, which can be achieved through levels of flexibility and the ability of employees (Ung and Norng, 2017). From a study on the hotel industry, there is a supported result showing that there is a significant positive relationship between responsiveness and customer's satisfaction (Phi et al., 2018). As for a food and beverage (F\&B) industry, the data from UK researches showed that, with a supported result of all hypothesises, it proved that responsiveness has a positive significant relationship with customers' satisfaction in UK restaurants (Nguyen, 2018).

Again, findings in the research data from Pakistan and Irbid city, Jordan confirmed that the hypothesis is accepted, which claimed that responsiveness has a positive impact to customer's satisfaction (Ali and Raza, 2017; Al-Azzam, 2015). In the airline service industry, the research data from Jordan came out a result proved that responsiveness has a significant positive relationship with passengers' satisfaction (Jahmani, 2017).

\section{Empathy}

Empathy is defined as a kind of compassion, which is the company's care and personal attention to customers (Hofelich and Preston, 2012). Research result showed that there is a significant positive relationship between empathy and student's satisfaction (Kajenthiran, 2015; Mahmoud and Grigoriou, 2017). Moreover, the research data from the American Psychological Association explained that there is a significant relationship linking both facility support and student-peer support and student's satisfaction. (Tompkins, Brecht, Tucker, Neander and Swift, 2016).

Besides, research showed that empathy is categorized together with assurance and tangibles as the most affecting factors that influence student satisfaction, there is a significant relationship with empathy represented the value $r=.36, p<.05$ which is statistically highly significant at the. 000 levels (Pohyae, 2016), means that there is a significant relationship connecting empathy and student's satisfaction.

\section{Theoretical Framework}

According to all the previous literature, it can be determined the 5 dimensions of SERVQUAL model (tangibles, assurance, reliability, responsiveness, and empathy) consider as important factors affecting undergraduates' satisfaction in Malaysian Private University. The framework is described as follows: the dependent variable (DV) for this research study is undergraduates' satisfaction. There were various literature reviews proved that those independent variables (tangibles, assurance, reliability, responsiveness, and empathy) have a positive relationship with and have impacts on the dependent variable. 


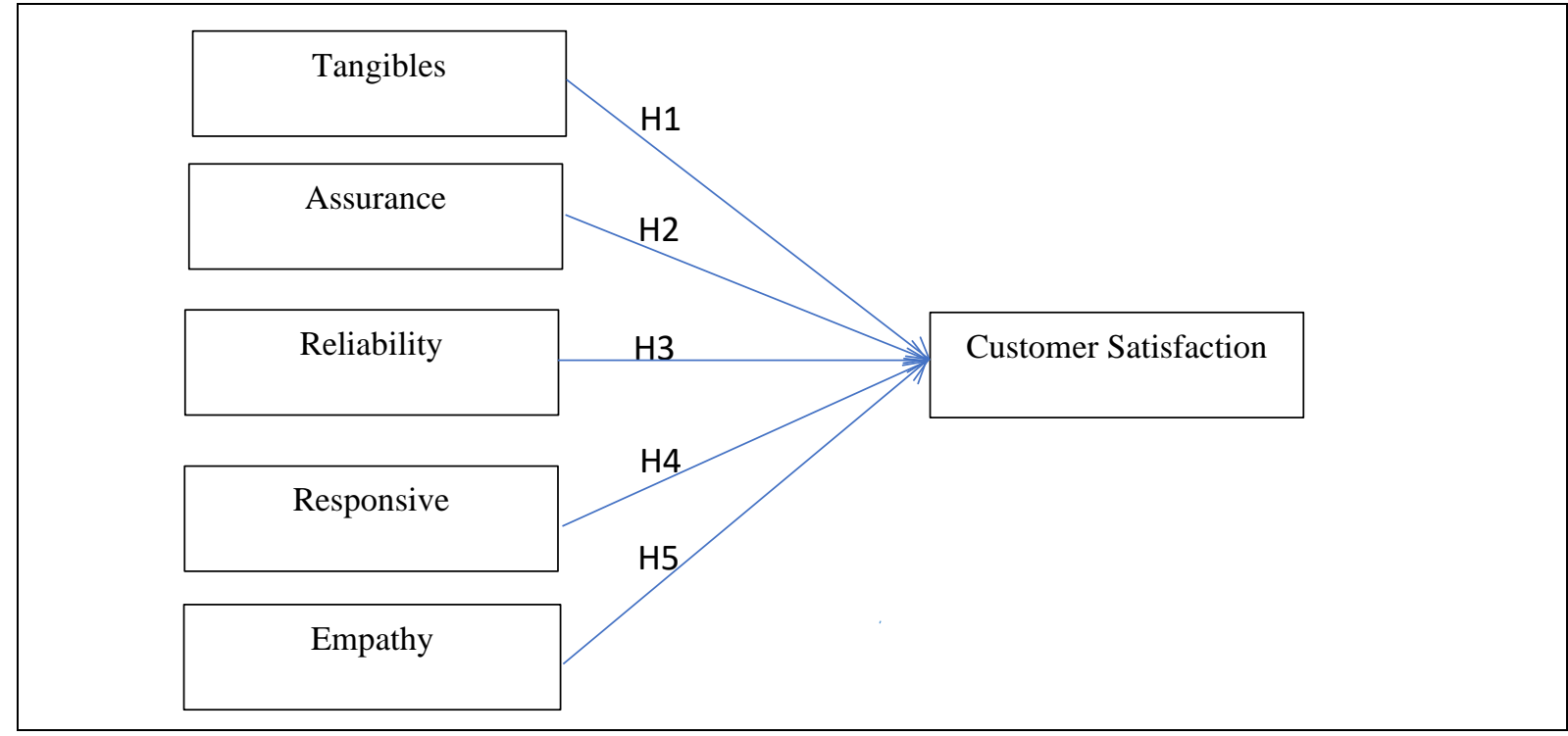

Figure 1: Research Framework

\section{Hypothesis Development}

The hypotheses of this research are stated as per below:

$\mathrm{H} 1$ : Tangibility significantly predicts the customer satisfaction model.

$\mathrm{H} 2$ : Assurance significantly predicts the customer satisfaction model.

H3: Reliability significantly predicts the customer satisfaction model.

H4: Responsive significantly predict the customer satisfaction model.

H5: Empathy significantly predicts the customer satisfaction model.

\section{Research Design}

The MBA students of private universities will be the unit of analysis in this research, and the main focus area for this research study is private universities in Selangor Malaysia. Sample size may impact the detection of a significant relationship, differences or interactions (James et al., 2001). Based on the Raosoft calculation, a total of 288 sample size should be an acceptable sample size for this study from a huge population of private university students in Malaysia.

The target population in this study was concentrated with the students in private universities in Selangor Malaysia. The judgment behind to choose Selangor state is, it is a high population city and becoming the centre of the country area, there are several private universities located at that particular area and therefore the population of private university's students are much higher than other states.

Researcher distributes the questionnaires to the students in private universities in Selangor Malaysia. The sampling technique that used is convenience sampling, which is a nonprobability sampling technique, the researcher selected this technique for a reason that this technique is a convenience for the researcher to distribute the questionnaire as the message in the questionnaire are easier to reach respondents and convenience for the researcher to collect data (Dorherty, 1994). The researcher distributed the questionnaires to the students in private universities in Selangor Malaysia.

The researcher can save time by adjusting and correcting the questions in the questionnaire by referring to the questionnaires created by the previous researcher who does the research 
related to this study. Questionnaires were distributed via email. A total of 288 questionnaires were randomly selected and spread to students from private universities in Malaysia.

\section{Data Analysis and Results}

Table 1: Reliability Analysis

\begin{tabular}{|c|c|c|}
\hline & Cronbach's Alpha & $\begin{array}{c}\text { N of } \\
\text { Items }\end{array}$ \\
\hline SATIS & .690 & 4 \\
\hline TANG & .608 & 4 \\
\hline ASS & .606 & 4 \\
\hline REL & .604 & 4 \\
\hline RES & .601 & 4 \\
\hline EMP & .618 & 5 \\
\hline Overall & .763 & 25 \\
\hline
\end{tabular}

Based on table 1 above, there are signals that Satisfaction (SATIS), Tangibles (TANG), Assurance (ASS), Reliability (REL), Responsiveness (RES), and Empathy (EMP). The Cronbach's Alpha is $0.690,0.608,0.606,0.604,0.601$ and 0.618 respectively, showing that the reliability of every variable is acceptable as all of the values are more than 0.6. However, the overall Cronbach's Alpha is 0.763 , showed that satisfactory result, the result is mean that the scale of the questionnaire is positive.

Therefore, overall, the questionnaire is reliable because the result proved good reliability.

\section{Hypothesis Testing}

Table 2: ANOVA Test

\section{ANOVA}

\begin{tabular}{|c|c|c|c|c|c|c|}
\hline Model & & $\begin{array}{l}\text { Sum } \\
\text { Squares }\end{array}$ & df & Mean Square & $\mathrm{F}$ & Sig. \\
\hline \multirow[t]{3}{*}{1} & Regression & 8.776 & 5 & 1.755 & 12.385 & $.000 b$ \\
\hline & Residual & 36.280 & 256 & .142 & & \\
\hline & Total & 45.057 & 261 & & & \\
\hline
\end{tabular}

a. Dependent Variable: Satisfaction

b. Predictors: (Constant), Empathy, Tangibles, Responsiveness, Reliability, Assurance

According to table 2 above, the ANOVA test result shows the significant $F$-test ( $F=12.385$, $p$-value $<0.01$ ), proved that the combination of independent variables significantly predicted dependent variable. 
Table 3: Coefficients

\begin{tabular}{|c|c|c|c|c|c|c|c|c|}
\hline \multicolumn{2}{|c|}{ Model } & \multicolumn{2}{|c|}{$\begin{array}{l}\text { Unstandardized } \\
\text { Coefficients }\end{array}$} & $\begin{array}{l}\text { Standardize } \\
\mathrm{d} \\
\text { Coefficients } \\
\text { Beta }\end{array}$ & . & Sig. & \multicolumn{2}{|c|}{$\begin{array}{l}\text { Collinearity } \\
\text { Statistics }\end{array}$} \\
\hline 1 & (Constant) & 2.318 & .426 & & 5.441 & .000 & & \\
\hline & Tangibles & .318 & .089 & .246 & 3.579 & .000 & .665 & 1.504 \\
\hline & Assurance & -.312 & .096 & -.256 & -3.241 & .001 & .505 & 1.978 \\
\hline & Reliability & .036 & .104 & .026 & .342 & .733 & .531 & 1.882 \\
\hline & $\begin{array}{l}\text { Responsivene } \\
\text { ss }\end{array}$ & -.144 & .093 & -.117 & -1.545 & .124 & .548 & 1.826 \\
\hline & Empathy & .493 & .073 & .435 & 6.781 & .000 & .764 & 1.309 \\
\hline
\end{tabular}

a. Dependent Variable: Satisfaction

The purpose of Multiple Regression Analysis is to propose a prediction model of a research study and also to examine the relationship between two variables.

According to table 3 above, the final regression equation stated as the following:

\section{SATIS $=2.318+0.318$ (Tangibles) -0.312 (Assurance) +0.493 (Empathy)}

Based on the data on table 3 , it showed that Tangible has a significant positive effect on Satisfaction (beta $=0.246, P<0.001$ ). Assurance has a significant negative effect on Satisfaction (beta $=-0.256, \mathrm{P}<0.01$ ). Reliability has no significant positive effect on Satisfaction (beta $=0.026, \mathrm{P}>0.001$ ). Responsiveness has no significant positive effect on Satisfaction (beta $=-$ $0.117, \mathrm{P}>0.01$ ); Empathy had a significantly positive impact on Satisfaction (beta $=0.435$, $\mathrm{P}<0.001)$.

In conclusion, by looking at all the results of the above analysis, the researcher had made wrapping up and stated as table 4 as the following:

Table 4: Hypothesis Results

\begin{tabular}{|c|c|c|}
\hline \multicolumn{2}{|r|}{ Hypotheses } & Results \\
\hline $\mathrm{H} 1$ & $\begin{array}{l}\text { Tangibility significantly predict the customer satisfaction } \\
\text { model }\end{array}$ & Supported \\
\hline $\mathrm{H} 2$ & $\begin{array}{l}\text { Assurance significantly predict the customer satisfaction } \\
\text { model }\end{array}$ & Supported \\
\hline $\mathrm{H} 3$ & $\begin{array}{l}\text { Reliability significantly predict the customer satisfaction } \\
\text { model }\end{array}$ & $\begin{array}{c}\text { Not } \\
\text { Supported }\end{array}$ \\
\hline $\mathrm{H} 4$ & $\begin{array}{l}\text { Responsiveness significantly predict the customer } \\
\text { satisfaction model }\end{array}$ & $\begin{array}{c}\text { Not } \\
\text { Supported }\end{array}$ \\
\hline H5 & $\begin{array}{l}\text { Empathy significantly predict the customer satisfaction } \\
\text { model }\end{array}$ & Supported \\
\hline
\end{tabular}

Hypotheses 1, 2 and 5 are supported. 


\section{Conclusion and Recommendation}

Among the total number of the respondents, $52 \%$ are male and $48 \%$ are female ages between 26-30 years old with an undergraduate degree as the highest education level. They are mostly single with an average monthly income between RM3,001.00 and RM5,000.00

This research provides noteworthy participation in a recent study. Previous research has analyzed companies from the perspective of consumers, while less research has managed the enhancement of service quality, especially private universities. The study provides useful, comprehensive information for future research on identifying factors influencing student satisfaction in private universities. The need to emphasize tangibility and empathy are important for this segment of customers. The need to have high empathy in the services industry indeed is the most important as proven in this study which had the highest beta value of almost 0.5 . Thus, continue to serve with empathy in mind is paramount in producing the sataufaction in the universities.

This conceptual framework serves as a guide in measuring customer satisfaction and the influence of the provided services. During the research process, top managers and practitioners could consider to be responsible and to apply the conceptual framework into two aspects-organization and environment. The study found a negative impact from assurance which may need further examination in future studies.

Enhancing service quality helps to attract more loyal customers and hence increase the company's revenue. While a company can operate well, there will be a good economic development for the country as well. The research results about SERVQUAL brought constructive advice to various industries including the education industry.

\section{References}

Abdullah, F. (2006). The development of HEdPERF: a new measuring instrument of service quality for the higher education sector. International Journal of Consumer Studies, 30(6), pp.569-581.

Azam, A. (2018). Service Quality Dimensions and Students' Satisfaction: A study of Saudi Arabian Private Higher Education Institutions. European Online Journal of Natural and Social Sciences. 7(2) pp. 275-284

Al-Azzam, A. F. M. (2015). The impact of service quality dimensions on customer satisfaction: A field study of Arab bank in Irbid city, Jordan. European Journal of Business and Management, 7(15), pp.45-53.

Ali, M., \& Raza, S. A. (2017). Service quality perception and customer satisfaction in Islamic banks of Pakistan: the modified SERVQUAL model. Total Quality Management \& Business Excellence, 28(5-6), pp.559-577.

Anwowie, S., Amoako, J., \& Abrefa, A. A. (2015). Assessment of Students' Satisfaction of Service Quality in Takoradi Polytechnic: The Students' Perspective. Journal of Education and Practice, 6(29), pp.148-155.

Dora, Y. M. (2017). Analysis Effect of Service Quality, Educational Facilities, and Method of Learning, Student Satisfaction and Loyalty to Students-Studies in the University of Widyatama Bandung. European Journal of Social Science Education and Research, 4(3), pp.16-27.

Dorherty, M. (1994). Probability versus non-probability sampling in the sample. The NewZealand Statistics Review, p 21-28.

Douglas, J., Douglas, A., \& Barnes, B. (2006). Measuring Student Satisfaction at a UK University. Quality Assurance in Education. 14. 251-267. 
Drucker, P. (1954). The Practice of Management. Harper \& Row, New York, NY.

Minh-Quang, D. (2015). University Experiences and Satisfaction of Vietnamese University Students. Journal of Studies in Education. 5(4). Pp 90-99.

Etawau.com. (2019). Malaysian Private Universities. [online]. Available at: http://www.etawau.com/edu/IndexUniversityPrivate.htm[Accessed 15 November 2019].

Guilbault, M. (2018). Students as customers in higher education: The (controversial) debate needs to end. Journal of Retailing and Consumer Services. 40, pp.295-298.

Haihambo, J. (2018). An investigation of students' perceptions of service quality at the Namibia Business School (Doctoral dissertation, University of Namibia).

Hofelich, A. J., and Preston, S. D. (2012). The meaning in empathy: Distinguishing conceptual encoding from facial mimicry, trait empathy, and attention to emotion. Cognition \& Emotion, 26(1), pp.119-128.

Jahmani, A. (2017). The effect of Royal Jordanian Arline service quality on passsengers's satisfaction.. International Journal of Business and Society, 18(S3), pp.519-530.

James, E., Bartlett, I., Kotrlik, J. W., \& Higgins, C. C. (2001). Organizational research: determining appropriate sample size in survey research. Information Technology, Learning, and Performance Journal, 19(1), p 43-50.

Kajenthiran, K., \& Karunanithy, M. (2015). Service Quality and Student Satisfaction: A Case Study of Private External Higher Education Institutions in Jaffna, Sri Lanka. Journal of Business, 1(2).

Kotler, P. (1977). From sales obsession to marketing effectiveness. Harv. Bus. Rev. 55 (6), pp 67-75.

Kunanusorn, A., \& Puttawong, D. (2015). The Mediating effect of satisfaction on student loyalty to higher education institution. European Scientific Journal (Special Edition), 1, pp.449-463.

Lenton, P. (2015), "Determining Student Satisfaction: An Economic Analysis of the National Student Survey", Economics of Education Review, vol. 47, pp. 118-127.

Li, I. W., \& Carroll, D. (2017). Factors Influencing University Student Satisfaction, Dropout and Academic Performance: An Australian Higher Education Equity Perspective. National Centre for Student Equity in Higher Education (NCSEHE), Perth: Curtin University.

Mahmoud, A. B., \& Grigoriou, N. (2017). When empathy hurts: Modelling university students' word of mouth behaviour in public vs. private universities in Syria. Higher Education Quarterly, 71(4), pp.369-383.

Malaymail.com. (2019). Education Ministry: Revenue from international students expected to grow to RM15.6b. [online] Available at:

https://www.malaymail.com/news/malaysia/2019/09/12/education-ministryrevenue-from-international-students-expected-to-grow-to/1789792 [Accessed 15 November 2019].

Nguyen, Q., Nisar, T. M., Knox, D., \&Prabhakar, G. P. (2018). Understanding customer satisfaction in the UK quick service restaurant industry: The influence of the tangible attributes of perceived service quality. British Food Journal, 120(6), pp.1207-1222.

Yahaya, N. (2019). Recent Development of the International Higher Education in Malaysia Challenges and Opportunities. EURIE Eurasia Higher Education Summit 2019 (EURIE2019). Istanbul. pp1-26. 
Phi, H. D., Thanh, L. P., \& Nguyen Viet, B. (2018). Effects of service quality on customer satisfaction and customer loyalty: A case of 4-and 5-star hotels in Ho Chi Minh City, Vietnam. Business and Economic Horizons (BEH), 14(1232-2019-848), pp.437-450.

Pohyae, S., Romle, A. R., Saleh, N. H., Saleh, S., \& Mohamood, K. B. (2016). The Relationship Between Service Quality and Student Satisfaction: The Case of International Students in Public University. World Applied Sciences Journal, 34(4), pp.491-498.

Sin, M. C., Yusof, B. B., \& Sin, K. Y. (2018). International Students' Satisfaction Level towards Service Quality in Academic Aspect and Loyalty to Universiti Teknologi Malaysia. International Journal of Academic Research in Business and Social Sciences, 8(10).

Theresia, L., \& Bangun, R. (2017). Service quality that improves customer satisfaction in a university: a case study in Institut Teknologi Indonesia. In IOP Conference Series: Materials Science and Engineering. 277(1), p. 12-59.

Thien, L. M., \& Jamil, H. (2019). Students as 'Customers': unmasking course experience and satisfaction of undergraduate students at a Malaysian Research University. Journal of Higher Education Policy and Management, pp.1-22.

Tompkins, K. A., Brecht, K., Tucker, B., Neander, L. L., \& Swift, J. K. (2016). Who matters most? The contribution of faculty, student-peers, and outside support in predicting graduate student satisfaction. Training and Education in Professional Psychology, 10(2), p.102.

Twaissi, N. M., \& Al-Kilani, M. H. (2015). The Impact of Perceived Service Quality on Students' Intentions in Higher Education in a Jordanian Governmental University. International Business Research, 8(5), p.81.

Ung, V., \& Norng, T. (2017). Gearing Service Quality into High Educational Institutes in Cambodia. Archives of Business Research, 5(9).

Xiao, J., \& Wilkins, S. (2015). The effects of lecturer commitment on student perceptions of teaching quality and student satisfaction in Chinese higher education. Journal of Higher Education Policy and Management, 37(1), pp 98-110. 